DANMARKS GEOLOGISKE UNDERSØGELSE

III. Række. Nr. 46

Geological Survey of Denmark. III. Series. No. 46

\title{
Mapping of hydrochemical data by computer at the Geological Survey of Denmark
}

BY

Arne Villumsen and Jens Jacobsen

DANSK SAMMENDRAG

Kortlogning af hydrokemiske data ved hjolp of $E D B$

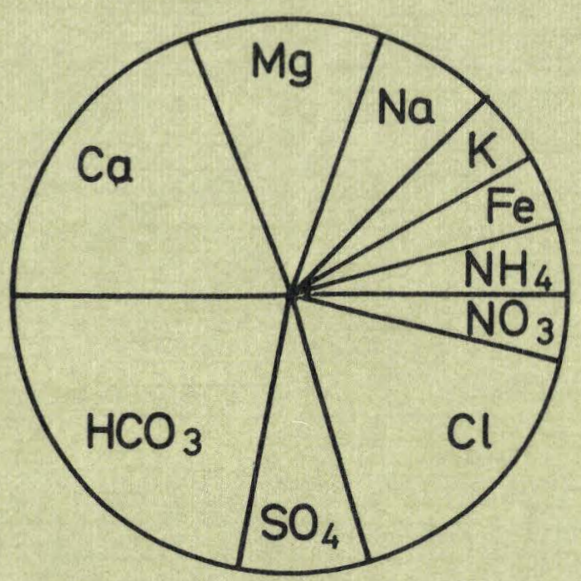


Danmarks Geologiske Undersøgelse . III. Række. Nr. 46

Geological Survey of Denmark . III. Series. No. 46

\section{Mapping of hydrochemical data by computer at the Geological Survey of Denmark}

By

Arne Villumsen and Jens Jacobsen

Dansk sammendrag:

Kortlægning af hydrokemiske data ved hjælp af EDB

I kommission hos C. A. Reitzels Forlag København 1977 
D.G.U. III. rk. nr. 46

er sat med Linotype Times

og trykt i offset i 1000 eksemplarer hos Andelsbogtrykkeriet i Odense.

Bogen er trykt på Thai-Cote, $115 \mathrm{~g}$ fra a/s De forenede Papirfabrikker. ISBN 87-421-0706-7

ISSN 0366-9149

With 2 plates

Date of publication: 1977-03-31 


\section{Contents}

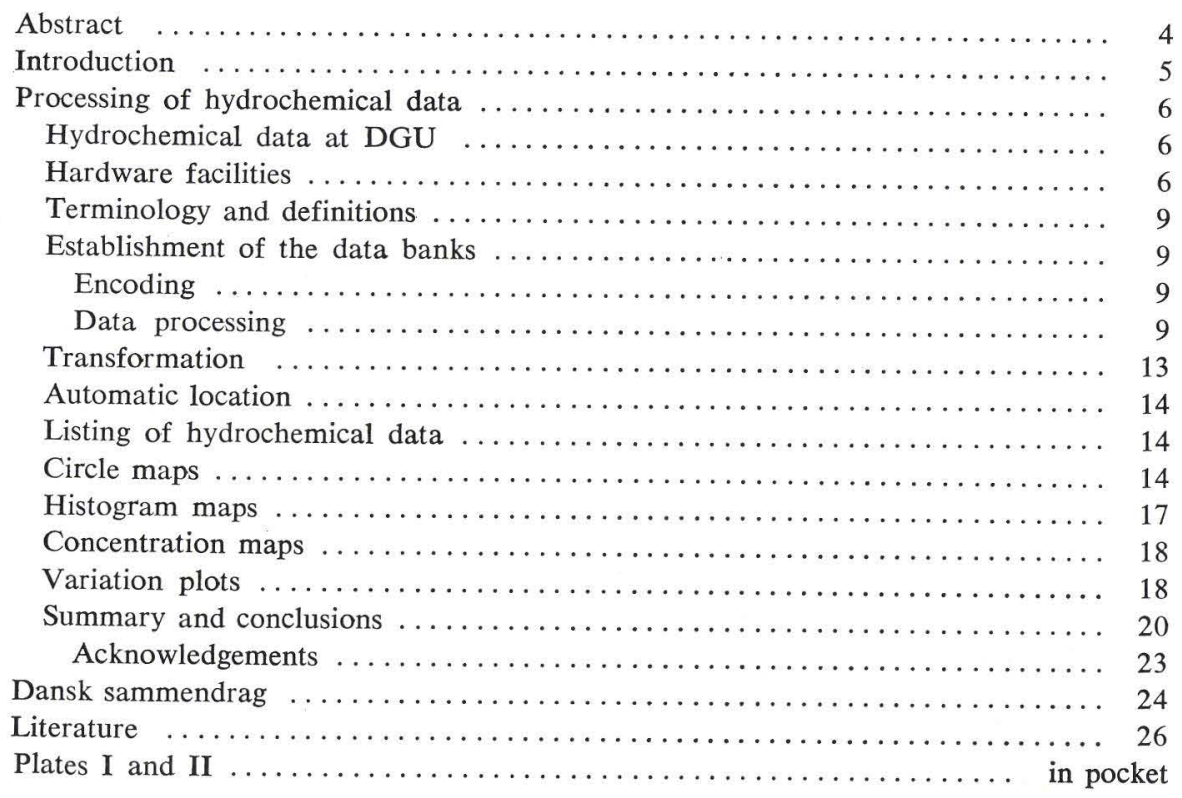




\section{Abstract}

In the present paper an outline is given of the actual use of computers to represent hydrochemical data at the Geological Survey of Denmark. Special emphasis is directed to the description of the different types of output. 


\section{Introduction}

Since about 1930, ground-water analyses have been systematically registered in a file at the Geological Survey of Denmark (DGU). Today this file contains about 10,000 ground-water analyses, representing virtually the whole country of Denmark. The majority of the analyses have been collected from a number of commercial analytical laboratories in Denmark, while part of the analyses have been performed at the Survey. The lastmentioned group of analyses are mostly from gxound-water reservoirs where the water supply has caused some problems, in as much as the Survey is normally consultated only in such cases. This means that a certain lack of representativity of the ground-water file for Denmark as a whole cannot be excluded.

By the Water Supply Act of 1973 the counties will have to map the groundwater chemistry, amongst other things. The analyses in the file at the Survey are used as the preliminary basis for this mapping operation, as this file at present is the most suitable file in Denmark. In most cases it is necessary to supplement the file by new representative analyses to obtain acceptable maps. This updating is also essential for the future use of the file for other purposes because the new analyses will increase the representativity of the ground-water file in general.

Another hydrochemical file has also been established at DGU, particularly during the last 20 years or so. This file contains at present some 10,000-12,000 surface-water analyses. Most of these analyses have been performed by DGU's chemical laboratory. The main purpose of this analythical work is to describe the weathering in Denmark and the transportation of chemical compounds in solution in the surface water. DGU has participated in the International Hydrological Decade programme (from 1967 to 1977), and this work has contributed essentially to the enlargement of the data file. 


\section{Processing of hydrochemical data}

\section{Hydrochemical data at DGU}

The ground-water file and the surface-water file both contain chemical data on mostly inorganic chemical components. The input form for surface water (fig. 1) gives an outline of the different variables. In the surface-water file, information about the sampling locality (river, lake, spring, etc.) is also included. The ground-water file contains data on almost the same variables, together with information about depth of sampling, type of water (purified, raw, etc.), the laboratory which has performed the analysis, and data for $\mathrm{CH}_{4}, \mathrm{H}_{2} \mathrm{~S}$, and excessive $\mathrm{CO}_{2}$.

The localization of the analyses in both files is based on a map division of Denmark at scale 1:40,000 (see fig. 2). Every map sheet has a number (from 1 to 247), and the analyses in the two files are indicated by this number, followed by a serial number for the different wells or rivers, for example " 56.412 " is a water analysis from well (or river - in the surfacewater file -) No. 412 on the 1:40,000 map sheet No. 56. The serial number gives no information about the well's location within the 1:40,000 map sheet.

The ground-water file as well as the surface-water file were manually updated and stored in traditional archives, but about 1973 DGU started data processing of the two files. The object of this was to facilitate both the mapping of the ground-water chemistry and the construction of various graphic displays to illustrate major variations in the surface-water chemistry.

\section{Hardware facilities}

At the commencement of the data processing project the Survey was equipped with a data terminal, a display unit (DATA 100), and a printer. The terminal can be connected to the computer at NEUCC (Technical University, Copenhagen) through the public telephone network. These hardware facilities were of course decisive for the building up of the procedure, as it was considered essential that the jobs could be initiated from the Survey. This

Fig. 1. Input form for surface-water analyses. 
KORT NR. $\bigsqcup_{19}$ Card No.

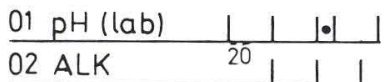

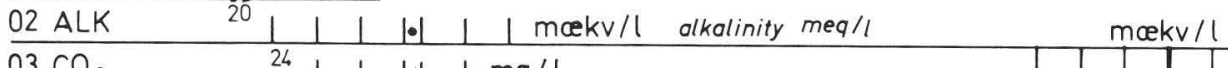

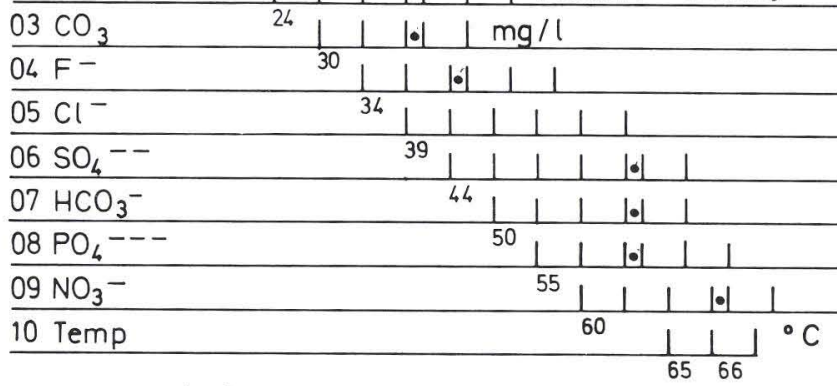

KORT NR. $\bigsqcup_{19}$ Card No.

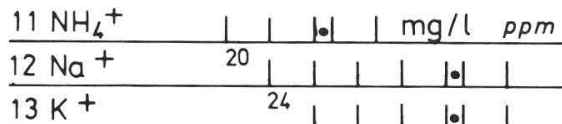

$14 \mathrm{Mg}^{++}$

$15 \mathrm{Ca}++$

$16 \mathrm{Fe}(<8 \mu)$

$17 \mathrm{Mn}++$

$18 \mathrm{Zn}++$

$19 \mathrm{SiO}_{2}$ ${ }^{30} \frac{1}{35}$

$20 \mathrm{KMnO}_{4}$ - tal

KORT NR. $\frac{1}{19}$ Card No.

$\frac{21 \mathrm{Al}^{+}+(<8 \mu) \mid}{22 \mathrm{Li}+}\left|\frac{\mid}{20}\right| \cdot|| \mathrm{mg} / 1 \mathrm{ppm}$

$\begin{array}{lllllllll}22 \mathrm{Li}+ & 20 & 1 & \mid & 1 \cdot 1 & \mid & \mathrm{ppb}\end{array}$

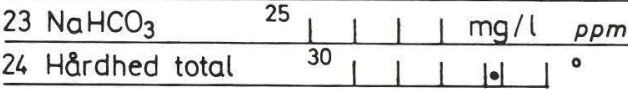

$1|1| \cdot||^{\circ}$ hardness, total

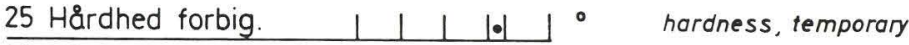

\begin{tabular}{ll|lll|llll}
26 & Hardhed bliv. & 1 & 1 & 1 & 1 & $1^{\circ}$ & hardness, permanent
\end{tabular}

$27 \mathrm{Fe}$ (total)

$28 \mathrm{pH}(\mathrm{felt})$

$29 \mathrm{Eh}$ (felt)

$30 \mathrm{~N}$ (org)

$31 \mathrm{P} \mathrm{(total)}$

$32 \mathrm{CO}_{2}$ (fri) $\frac{1}{33}|1 \cdot 1| 1$

$33 \mathrm{TU}(\mathrm{E})$

$34 \mathrm{TU}(\mathrm{B})$

$35 \mathrm{Fe}(<0.45 \mu)$

$36 \mathrm{Fe}^{++}(\mathrm{felt})$

$\left.\begin{array}{l}\rho H \\ E h\end{array}\right\}$ field measurement ${ }^{43}\left|\frac{1}{47}\right| 1 \mid \mathrm{mg} / 1 \mathrm{ppm}$

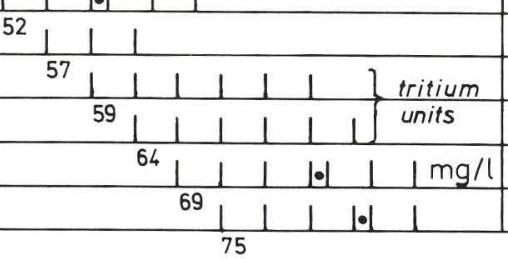

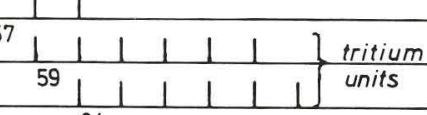




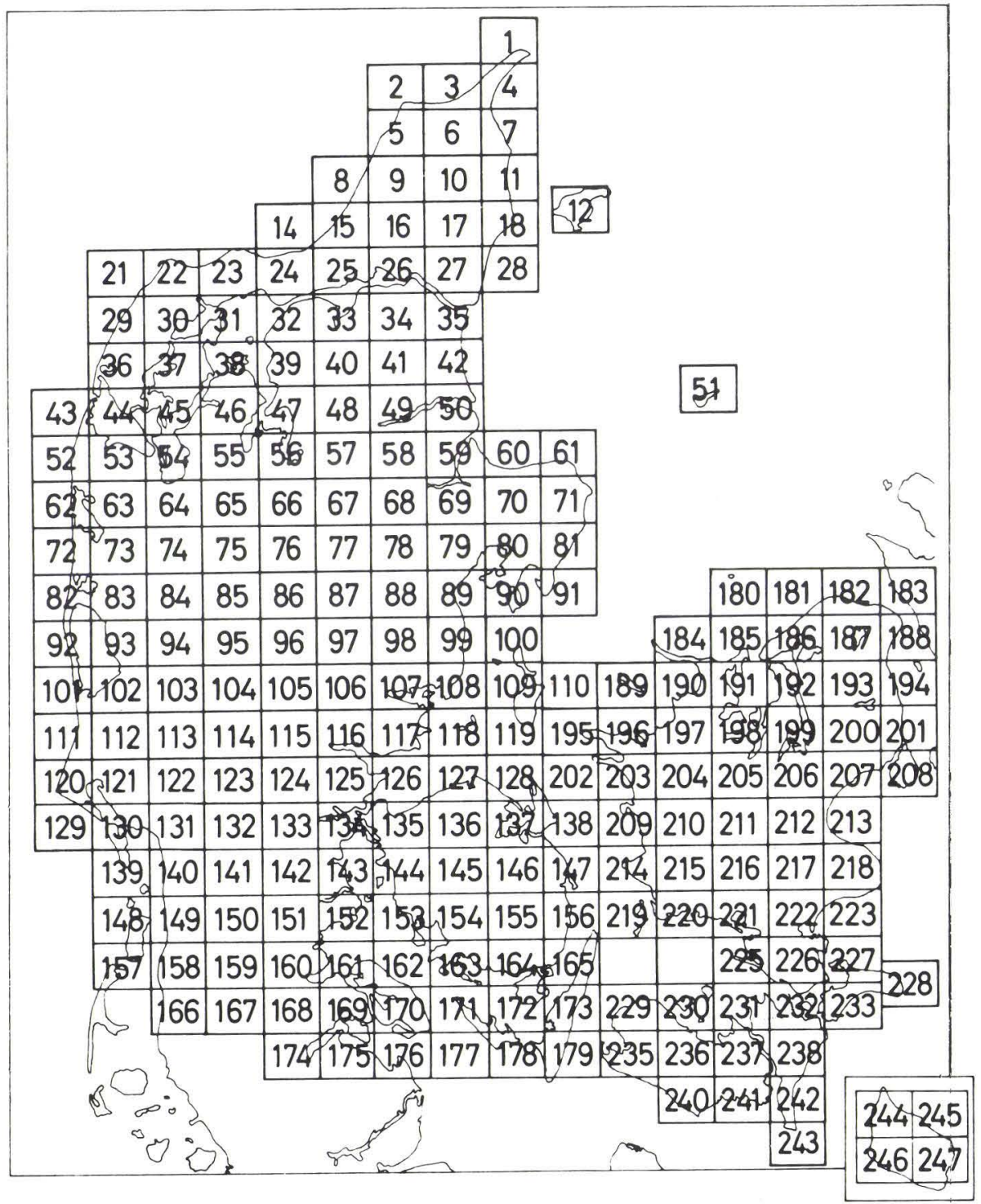

Fig. 2. Map sheet division of Denmark. Each square (numbered) represents an area covered by a $1: 40,000$ map sheet. 
requirement is fulfilled in the following fashion: The programmes are placed at NEUCC on a partitioned dataset (stored on a disc with direct access), from where each member (programme) can be fetched into the terminal store, manipulated in the proper manner and submitted to the computer as a batch-job. The original hydrochemical data (see p. 6) is stored at NEUCC on magnetic tapes, which are mounted by the operator according to the instructions laid down in the programme in question. The outputs are plotted or printed at NEUCC, from where they can be posted to the Survey. The printer at DGU is only used when the jobs are small because the transmission speed from NEUCC to the Survey is very slow.

\section{Terminology and definitions}

a) Data. In this context data means a number, a sign, or combinations of numbers and signs.

b) Identification. The identification of a water sample is the data describing the geographical location (map sheet and serial number), date of sampling, water type, sampling locality, and depth of sampling.

c) Variable. A variable is the data describing some measured or calculated chemical or physical property of a given water sample (e.g. $\mathrm{pH}$ value, temperature, alkalinity, $\mathrm{Na}$ concentration, etc.).

d) Analysis. By analysis is meant the identification and the variables of the sample in question.

\section{Etablishment of the data banks}

Encoding. To make the hydrochemical information available to the computer. the data are transferred to a data carrier. The Survey decided to use punched cards for this purpose. The data are transferred in a two-step process: Firstly the analyses are manually encoded on an input form (see fig. 1), which was designed in order to keep the punching costs at a low level, and which would also be usable for a manual check of the analyses in the old files. Secondly the input forms are sent to a punch bureau, where the data are transferred to punched cards by a keypunch, according to the instructions on the input forms.

Data processing. Fig. 3 shows an outline of the software system flow. The respective steps are labelled with a number, which is referred to in the following. 


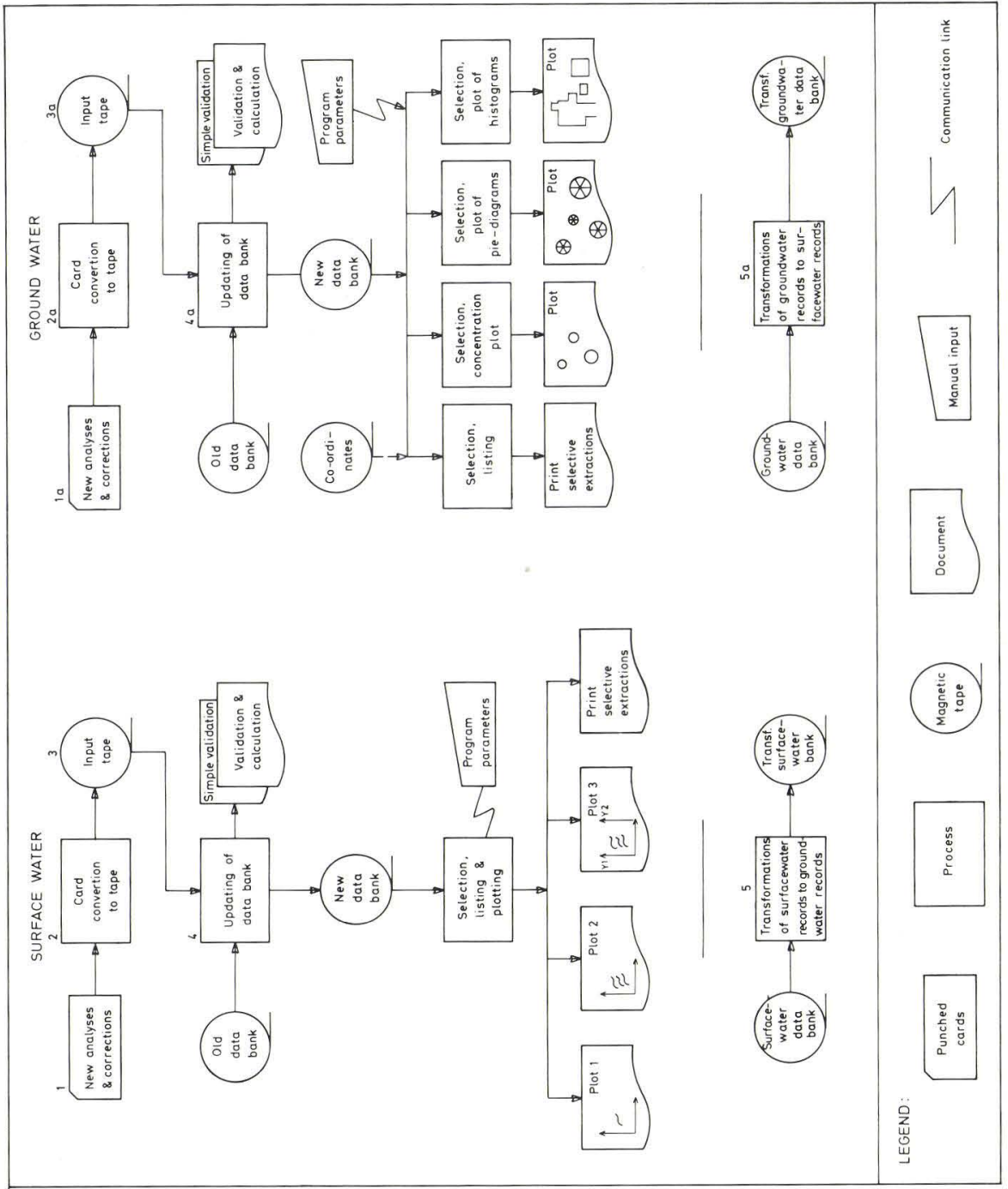

Fig. 3. Software system flow.

Input programme $(2,2 \mathrm{a})$. From the punched cards $(1,1 \mathrm{a})$ the data are transmitted to magnetic tape $(3,3 \mathrm{a})$. The card reader at NEUCC is used, as no card reader is available at DGU.

Updating programme $(4,4 a)$. Although different in some respects the updating programmes for ground water and surface water are very similar, and consequently only one of them (the surface-water programme, OOPDAT) will be described in the following. 
The programme is composed of the following sections:
A) Input
B) Sorting
C) Updating
D) Validation
E) Calculation

A) On the input tape each analysis makes up a record. A treatment code (1, 2 or 3 ) (see fig. 1) is assigned to each record describing whether the record is to be established (2) in the new data bank, or whether the corresponding record in the old data bank is to be corrected (3) or erased (1) partly or completely.

B) The records are sorted using a service sorting facility. The sorting order of the records is determined by the map sheet number, the serial number on the map sheet and the chronology (see fig. 5).

C) The updating section is a traditional updating routine, in which the input data are merged with the old data bank (see fig. 3).

D) This procedure has three steps. Firstly it is checked whether the operation given in the treatment code is valid; if not (e. g. correction (code 3) to a non-existing record) the operation is not executed, and an error message is given in the validation output, specifying what went wrong. Secondly the analyses are checked for invalid data (mainly due to punching errors). If invalid data are found, the record is accepted, but the variable in question is given the arbitrary value 0.00 and pointed out as wrong in the validation output (see fig. 4). This method has the advantage that only the improper variables need to be corrected in the following updating procedure. Thirdly the input variables containing signs are converted to numbers (e.g. $<0.01$ $\rightarrow 0.01$, TR (= trace) $\rightarrow 0$ etc.), so that they can be used in plots and calculations.

E) To be used as basic material the analyses must fulfil certain chemical requirements, and therefore calculations and tests are performed on the analyses, leading to the calculation output (see fig. 4), which is a valuable tool in the fault location procedure. Some examples of the calculations and tests are given below:

a) The difference between the calculated alkalinity (meq $\mathrm{CO}_{3}+$ meq $\mathrm{HCO}_{3}$ ), and the input alkalinity (ALK) must be less than 0.1 meq.

b) The difference between input total hardness and calculated hardness $(=2.8 \times($ meq $\mathrm{Ca}+$ meq $\mathrm{Mg}))$ must be less than 0.2 . 


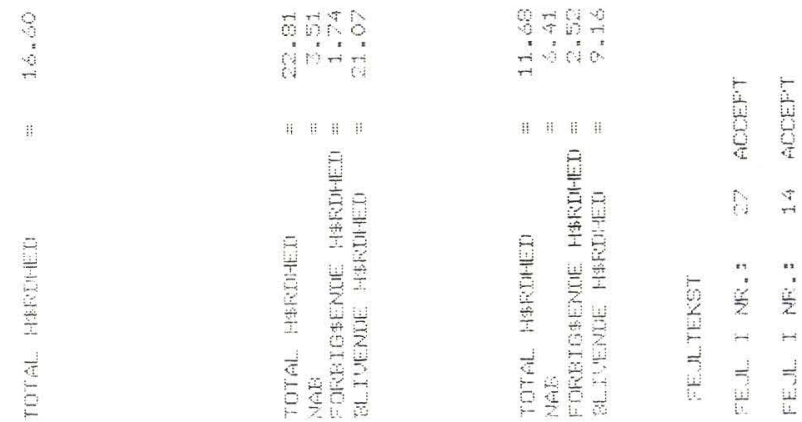

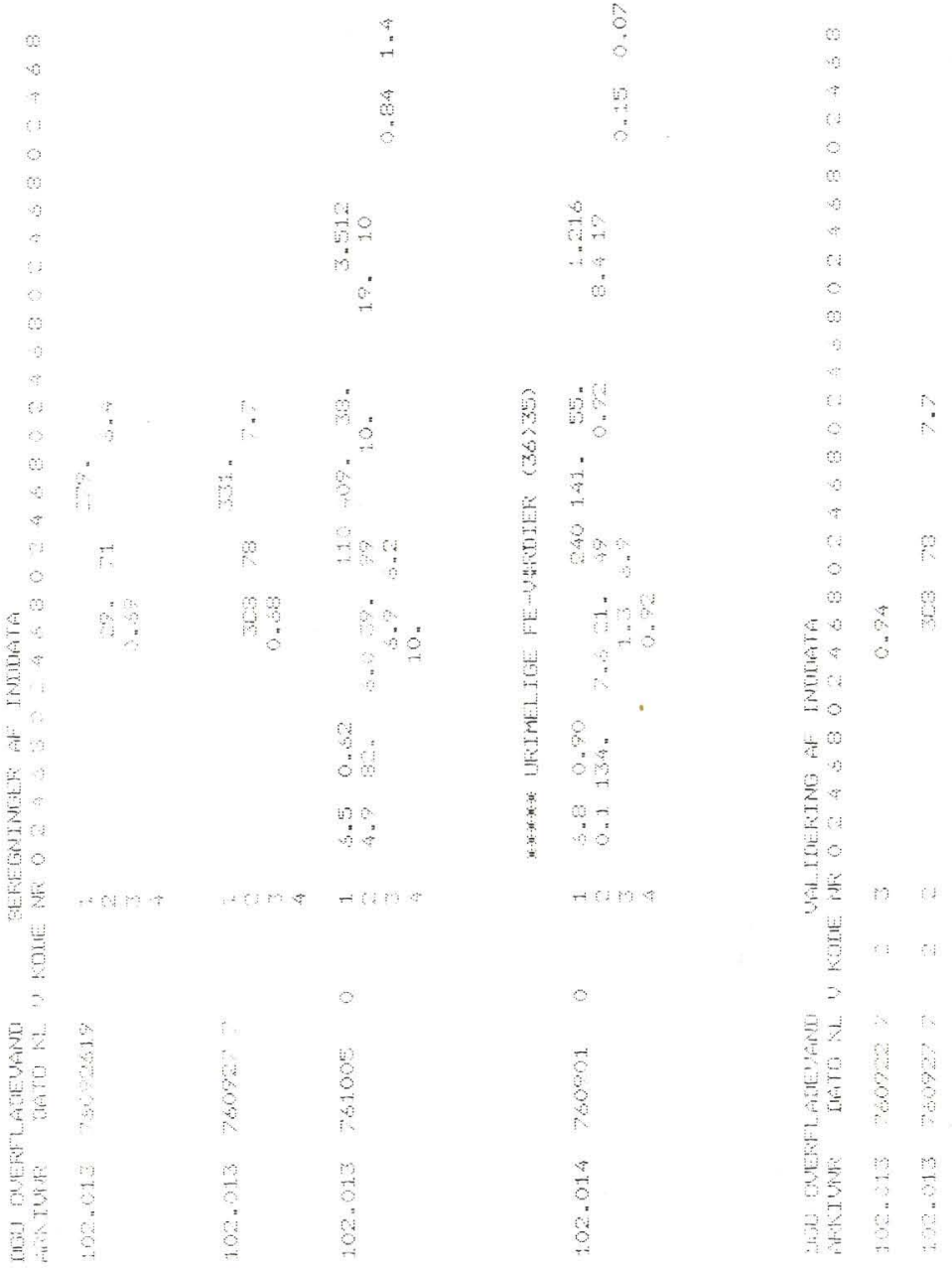

Fig. 4. Example of output from the test and calculation programme (OOPDAT). 
c) The difference between $\Sigma$ anions and $\Sigma$ kations must be less than 0.2 meq or less than $5 \%$ of $\frac{\sum \text { anions }+\sum \text { kations }}{2}$

d) If $\mathrm{ALK}>0$ and $\mathrm{ALK}>$ (meq $\mathrm{Ca}+$ meq $\mathrm{Mg}$ ), the difference between calculated $\mathrm{NaHCO}_{3}(=(\mathrm{ALK}-($ meq $\mathrm{Ca}+$ meq $\mathrm{Mg})) \times 84)$ and the input $\mathrm{NaHCO}_{3}(\mathrm{ppm})$ must be less than $10 \%$.

e) If $\mathrm{pH}$ is below $8.4, \mathrm{CO}_{3}$ must not be present.

f) The inequalities $\mathrm{Fe}^{2+} \leq \mathrm{Fe}(<0.45 \mu) \leq \mathrm{Fe}(<8 \mu) \leq \mathrm{Fe}_{\text {total }}$ must be true, if false, the variables are omitted from further treatment.

If the conditions are not fulfilled, an error message will be given (see fig.4). In the calculation output (fig. 4), the records involved in the updating procedure are listed together with the calculated values (e.g. total hardness) and the possible error messages. On the basis of this information the error corrections are carried out manually, encoded on punched cards, and used in a new updating procedure. In this way a new data bank consisting of controlled analyses is established. This bank is the basis for plots, lists, and other kinds of output.

\section{Transformation}

From the start of the data processing it was considered essential that the ground-water and surface-water analyses should be treated separately. This was done for the following reasons:

1) Some variables essential for the classification of ground water (e.g. $\mathrm{CH}_{4}$, excessive $\mathrm{CO}_{2}$ etc.) are not important for surface water and vice versa.

2) The different nature of the two water types is in general so important that a graphical display used for one water type will not be satisfactory for the other.

It should, on the other hand, be possible to use all the graphical illustrations for both ground water and surface water.

This problem is solved by connecting the two software systems with a transformation tape (see Nos. 5, 5a on fig. 3). When, for example, the time variation of some ground-water variables is to be plotted, the ground-water records are transformed to surface-water records and placed on a tape which is then used as input tape to the programme OFLVAND (see p. 18). 


\section{Automatic location}

For mapping purposes it is normally necessary to place the graphical illustration of the single analysis at the sampling location (well, river station etc.). This can either be done manually, as described on p. 17, or automatically by the computer, using co-ordinates.

Co-ordinates of the sampling localities are obtained from a co-ordinate table on which the map is placed in a rectangular co-ordinate system with its origin at the map's lower left corner.

From the co-ordinate table a paper tape is produced with identification and $(\mathrm{x}, \mathrm{y})$ values for the sampling locations, and the data are transferred to a magnetic tape (see fig. 3), which is merged with the hydrochemical data banks to obtain a plot. - It is outside the scope of the present paper to go into details about the co-ordinate digitizing procedures, as this is taken care of in another DGU department.

\section{Listing of hydrochemical data}

The need for an outline of the hydrochemical data is covered by the programmes GRLIST and OFLIST. The data are listed in the order given by the sorting (see p. 11), and as exemplified by OFLIST (see fig. 5), it is possible to extract any part of the data bank by the use of parameters governing the selection. Furthermore, the variables can be expressed in different units (e. g. ppm, meq/1 etc.).

The control parameters (01-05, see fig. 5) give the following information:

01 Map-sheet number(s).

02 Map-sheet number and serial number(s).

03 Either the variable(s) according to the number(s) to the left on the input form (see fig. 1), labelled with the proper units, or all the variables in the order given on the input form.

04 The period(s).

05 Sampling locality.

It should be mentioned that this extraction procedure is also the basis for the selection of data used in different statistical approaches at DGU.

\section{Circle maps}

Graphic illustrations of single ground-water analyses have earlier been used by several authors (Hem 1970). In order to illustrate the Danish 


\begin{tabular}{|c|c|c|c|c|c|c|c|c|}
\hline AFEIUNA & लिका वा.. & 4 & $\mathrm{NOH}$ & Mos in & NH & $M \omega \cdots$ & $\mathrm{FO}_{4}$ & 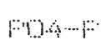 \\
\hline 18.01 & 0131 & 0 & 14 & 12.20 & ८०. $\mathbf{I}$ & $<n 1$ & .. & . 1.0 \\
\hline 18.01 & $\% 0301$ & 0 & 4,4 & .9 & $O_{n} 7$ & $-\%$ & 0.61 & .20 \\
\hline 16.61 & \%४०० & 0 & $y$ & 6,6 & ब $=$ & . 1. & 3,38 & - $1 \%$ \\
\hline 1.61 & 10430 & 0 & $33 n$ & $7,4: 3$ & 0.1 & $.0 \%$ & ${ }_{n}, 3 w_{3}$ & . Ift. \\
\hline ब. का & 6002 & o & 2. & ${ }_{n}, 0$ & 6 . & .0 & $1 \ldots 1$ & $\therefore$ \\
\hline $18 . \alpha 1$ & $\% 2 \%$ & 0 & $\therefore, \theta$ &.$\omega$ & o.1 & .06 & 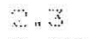 & $.7 \%$ \\
\hline 16.01 & \%०। & 0 & $\therefore \ldots$ & 1. $n-50$ & en & 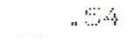 & o. & .0 \\
\hline 13.01 & $\% 901$ & ○ & $1 . \%$ & " & o n. & 0.1 & $\therefore z$ & .06 \\
\hline 18.001 & w1001. & o & $1 \%$ & $\ldots 94$ & 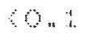 & 0.1 & 1. . : & 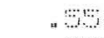 \\
\hline 18.01 & $110 \%$ & 0 & 1.6 & $3 \cdot 61$ & 0.4 & .31 & $2 \cdot 6$ &. \\
\hline 1. & 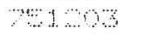 & & 26. & $\because .67$ & 2.7 & $\therefore 10$ & 1... & 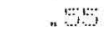 \\
\hline A. , को & 4010 & a & 6 & 10.6 & 0.4 & n1 & 2.0 & $n 6$ \\
\hline 19.001 & 3020 & 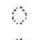 & 4.4 & 9.4 & $\therefore \circ$ & 1. $n$ & 1. .2 & .39 \\
\hline 9.01 & बिा & 0 & $46 n$ & $10, \% 9$ & 6.1 & 0.1 & 1.3 & $n$ \\
\hline $16=01$ & $\begin{array}{l}604 \\
60 \% 0\end{array}$ & 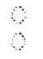 & $\begin{array}{l}32 \\
i \ldots n\end{array}$ & 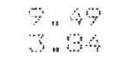 & at & $\mathrm{ona}^{1.10}$ & 1. 1.9 & a \\
\hline 18 " & 'डिन & 9 & $1.7 n$ & ; & $\alpha, \%$ & .. & 1. $n$ & 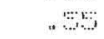 \\
\hline 16 . मो & बके & ? & ". & & $\therefore O_{1} 1$ & क. & $6=1$ & 1. .34 \\
\hline उ. बो & "sका: & $\partial$ & $1 \ldots .$. & .... 1. & ओ. 1 & 0.1 & 3,3 & 1. \\
\hline 19 , ब1 & किण & 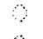 & $2 n$ & & ,,$\ldots$ & " : 6 & औ. & 1. . 4 \\
\hline$\omega$ a & 6100 & 0 & . . I. & 1.. & $\therefore$ n & 1. , 6 & $3 \times 3$ & 1. . \\
\hline . & 'का 1. & 0 & $1 \%$ & $\therefore \%$ & $\ldots .4$ & $1 . .6$ & $z_{n}, \cdots$ & 1. a 1.4 \\
\hline & & & 901 & $\mathrm{MO} / \mathrm{L}$ & $m / \ldots$ & $\mathrm{mi}, \mathrm{L}$ & Mil. & $10 . \ldots$ \\
\hline
\end{tabular}

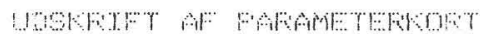

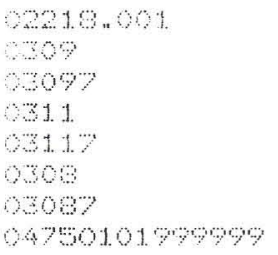

Fig. 5. Output from OFLIST.

ground-water chemistry the Survey decided to use a modified version of the pie-diagram, se fig. 6 . In this diagram a single chemical analysis is illustrated as a circle. The total area of the circle is proportional to the total ion concentration in the water sample. The distribution of the major ions $(\mathrm{Ca}, \mathrm{Mg}$, $\mathrm{Na}, \mathrm{HCO}_{3}, \mathrm{SO}_{4}, \mathrm{Cl}$, etc.) is shown by different circle sectors. The circles are calculated by the computer and plotted on special paper with Indian ink. As it appeared that the smallest circle sector which can be illustrated in a normal pie-diagram is ca. $5^{\circ}$, a routine was built into the programme which excludes ion concentrations below 3 per cent of the anion or kation sum (corresponding to an angle of 5.4 degrees) from being plotted. In most 

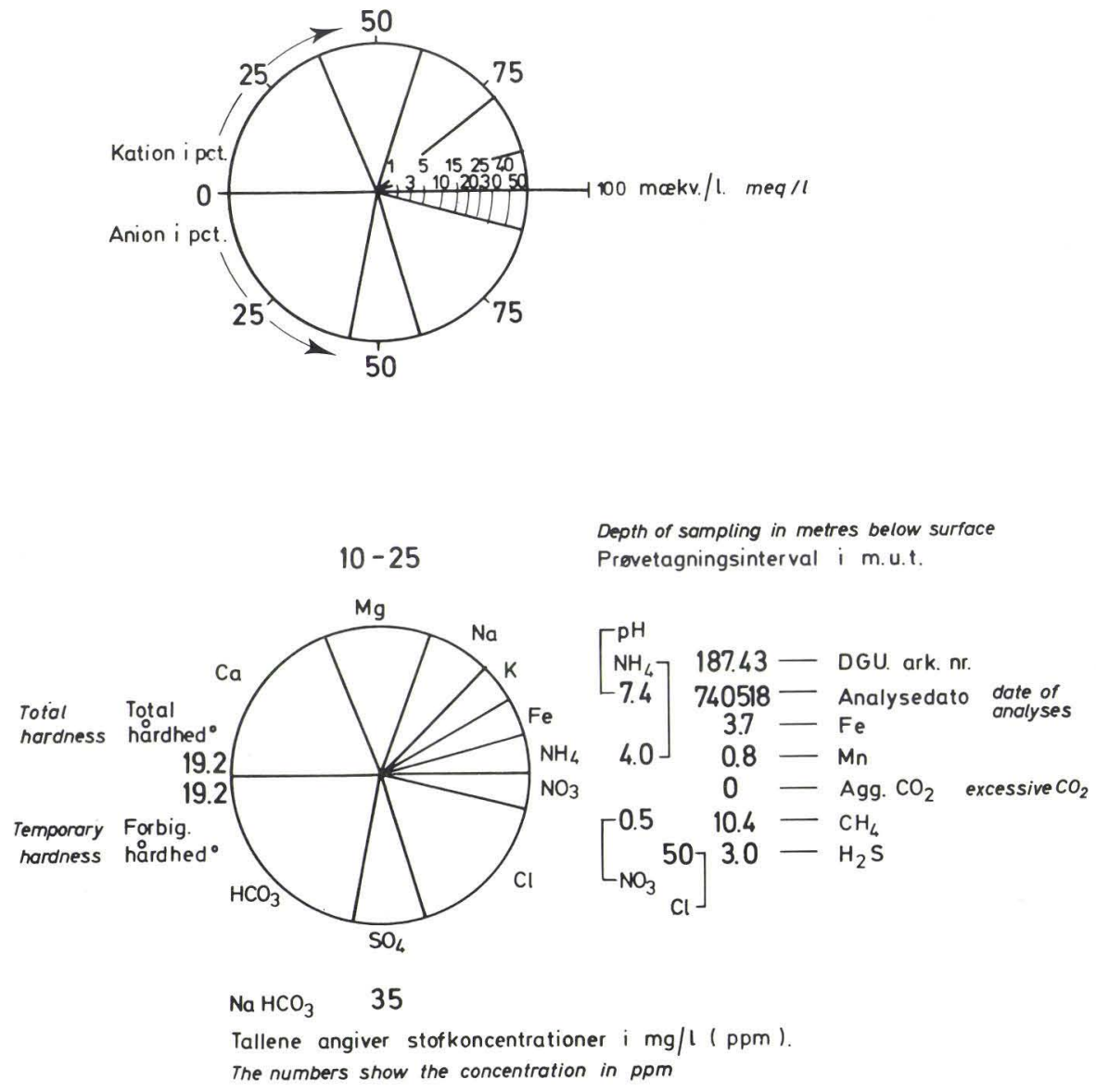

Fig. 6. Legend to pie-diagram.

cases the concentration of iron, manganese and ammonium are below the 3 per cent limit, and accordingly too small to be represented by a circle sector. It was therefore decided to specify the content of these elements by their ppm values (to the right of the circle, see fig. 6). Besides this, the concentrations of $\mathrm{H}_{2} \mathrm{~S}, \mathrm{CH}_{4}$, excessive $\mathrm{CO}_{2}$, and the $\mathrm{pH}$ value are shown, as these values cannot be accounted for in the circle illustration. As it is almost impossible in practice to read off the concentration of a specific element by means of the circle sector, a few variables, normally of special interest for water workers, are also shown by numbers around the circle (hardness, chloride content, etc.). The pie-diagram is the basic illustration of ground-water chemistry, and at present it is used all over Denmark in the counties' hydrochemical mapping. The counties produce the 
so-called hydrochemical basic-data maps (see plate 1) in which the piediagrams illustrate the single analyses. DGU has produced 3 analogous programmes to plot pie-diagrams:

GRPGM: In the data section of the programme the user must specify the map-sheet number and serial number of the boring (for example 36.412). The computer will then produce a plot of the newest water analysis from this boring, and in cases where several analyses from the same date are present in the data bank, the analysis from the deepest sampling depth is used.

GRPGM 2: The user indicates the map-sheet number (for example 36), and the computer will plot all the water analyses from map sheet No. 36 present in the data bank. The pie-diagrams are plotted in a series with constant intervals.

GRPGM 3: The user specifies the map-sheet number as for GRPGM 2, and the plotter draws the pie-diagrams placed exactly at the well's location, using the co-ordinate tape (see fig. 3). Only the newest analysis for each well is drawn (as for GRPGM).

The most convenient way to construct the hydrochemical maps is to plot all the circles automatically in a series by GRPGM 2 and afterwards to place them manually at the well locality on transparent paper. This procedure permits an evaluation of the data and sorting in cases where the file contains more data than can be shown on the final map. The basic-data maps for ground-water chemistry are reproduced as colour prints (see plate 1).

\section{Histogram maps}

In order to summarize large-scale variations in single chemical elements in the ground water, another type of mapping display (the histogram map) has been developed (see plate 2). The map is composed of a series of histograms showing the concentrations of a single chemical element (chloride in plate 2) and the number of analyses within minor geographical units. These units correspond to the 1:40,000 map-sheet division (see fig. 2).

To obtain a histogram plot the user must specify in the data section of the programme the selected variable, the division of the $\mathrm{x}$-axis, and the map sheet numbers if the plot includes only part of Denmark.

The division of the $\mathrm{x}$-axis in each histogram is selected for every element to give the most suitable grouping. In plate 2, for example, the chloride map gives the normal limit of taste for salt water, which is of special 
interest for water workers. If there is more than one chloride value for a boring without information about the sampling depth, only the highest concentration will be used in the map. If there is more than one chloride value for different sampling depths in the same boring, the highest chloride concentration for every new depth is included in the map.

The histogram maps give main lines for the specific element distribution in Denmark. This means that areas can easily be demarcated where a more detailed study of the chemistry is needed.

\section{Concentration maps}

Detailed information about the concentration of a selected variable can be obtained by maps produced by the programmes KLAT and KLAT 2. These programmes produce circles which are proportional to the concentration of the variable in question. The circles are placed automatically at the borings' location, using the co-ordinates described on p. 14. An example is shown in fig. 7.

To obtain concentration maps the user must specify the variable, the map sheet number(s), the map scale, and a factor selected to ensure that the size of the circles is sufficient to illustrate the variables' distribution pattern within the area mapped. To avoid an overlap between the different circles the user can specify which borings should be excluded from the plotting.

The concentration maps have mostly been used as a supplement to the histogram maps to obtain a more detailed impression of the hydrochemistry in areas where the variation pattern seems to be complicated.

\section{Variation plots}

The variation plot is a graphic illustration showing the variation of a number of variables (e.g. $\mathrm{pH}$ ) as a function of the time at a selected sampling station. The $\mathrm{x}$-axis serves as the time axis, and the $\mathrm{y}$-axis as the variable axis.

Three different types of plot are available, using the programme OFLVAND.

Fig. 7. Fluoride-concentration map. The size of the circles is proportional to the fluoride concentration, which is also shown to the right of the circles (in ppm). Above the circle the map sheet and serial number for the well and the sampling depth is indicated. 
1) One variable is plotted versus time

2) A number of variables are plotted versus time (see fig. 8)

3) A number of variables with different units are plotted versus time (see fig. 9).

The variation plot is used when different aspects of the surface-water chemistry are to be illustrated. As an example the plots can be mounted on a topographical background map (Jacobsen 1976) analogously to the mounting of pie-diagrams on the hydrochemical basic-data maps (see p. 17).

When a plot is to be run, the user must encode the plotting information parameters into the terminal store, save the information on the partitioned dataset, and activate the programme OFLVAND, which is designed to read the parameters governing the design of the plot.

The control parameters $(50-58)$ contain the following information:

50 The type of plot(s) and a list, showing the variables used in the plots.

51 The map sheet number(s).

52 The serial number(s) on a map sheet.

53 The variable(s), the unit on the $y$-axis per $\mathrm{cm}$, the type of unit (meq/1, ppm etc.), the length of the y-axis, the start value at origin on the $y$-axis (need not be 0.0 ), the y-axis to which the variables is connected (indicated only when plot 3 is used), and an upper and/or lower limit for the value of the variable in question.

54 The period(s).

55 The sampling locality.

57 The length of the $\mathrm{x}$-axis.

58 The height of the letters and signs used as labels.

These parameters can be mixed arbitrarily, which thus makes it possible to produce the plotting design and the numbers of plots needed.

\section{Summary and conclusion}

DGU's hydrochemical data processing project, which was started in 1973, has at present reached the following state: The two original hydrochemical files have been validated, corrected and converted to two data banks. From the data banks stored on magnetic tapes at the computing centre, NEUCC, information can be extracted automatically by the use of a telephone terminal placed at the Survey.

Fig. 8. Variation plot of $\mathrm{Fe}^{2+}, \mathrm{Fe}(<0.45 \mu)$ and $\mathrm{Fe}_{\text {tot }}$ for river station Nos. 102.063 and 94.004 (output from PLOT 2). 


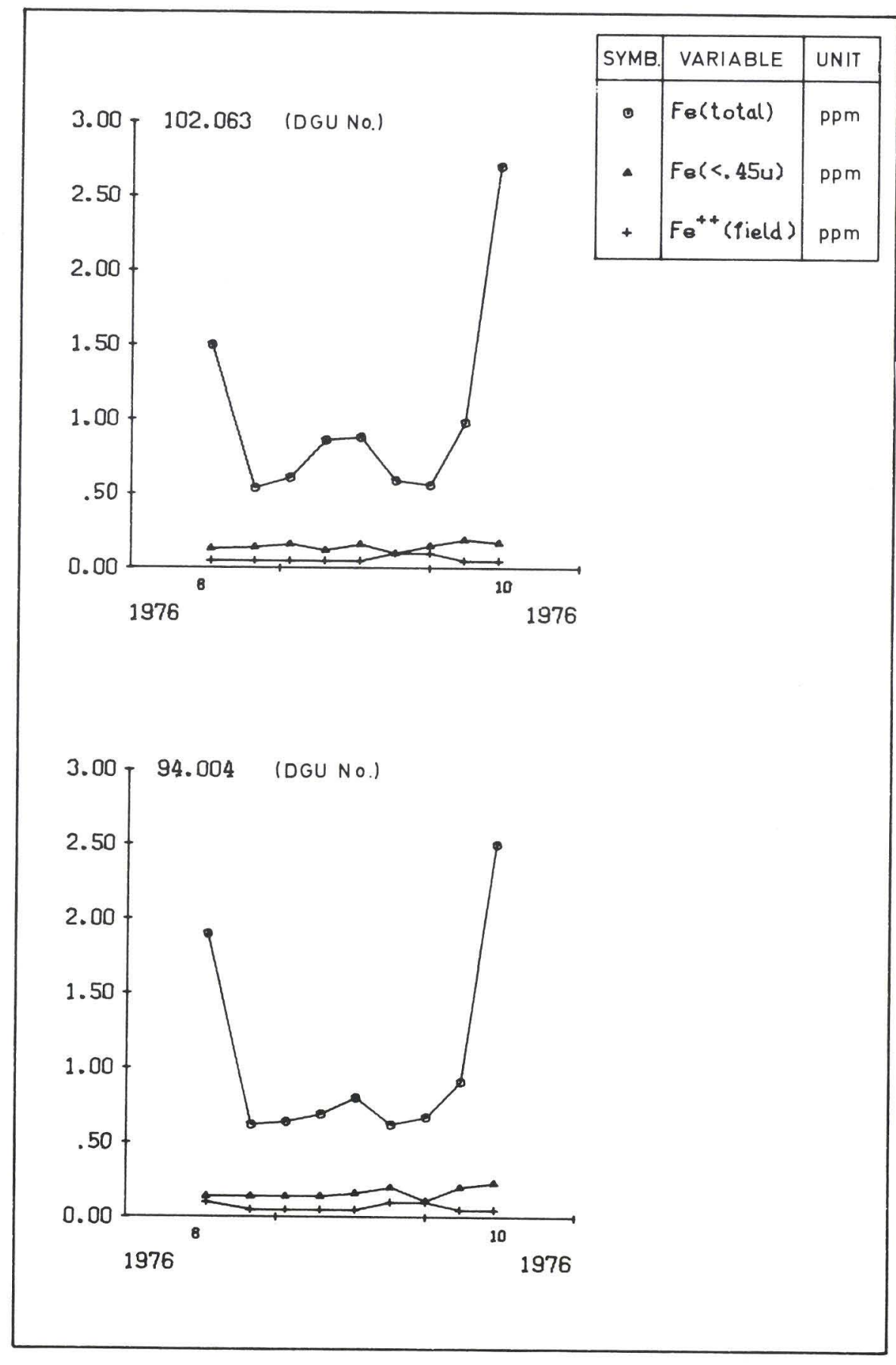




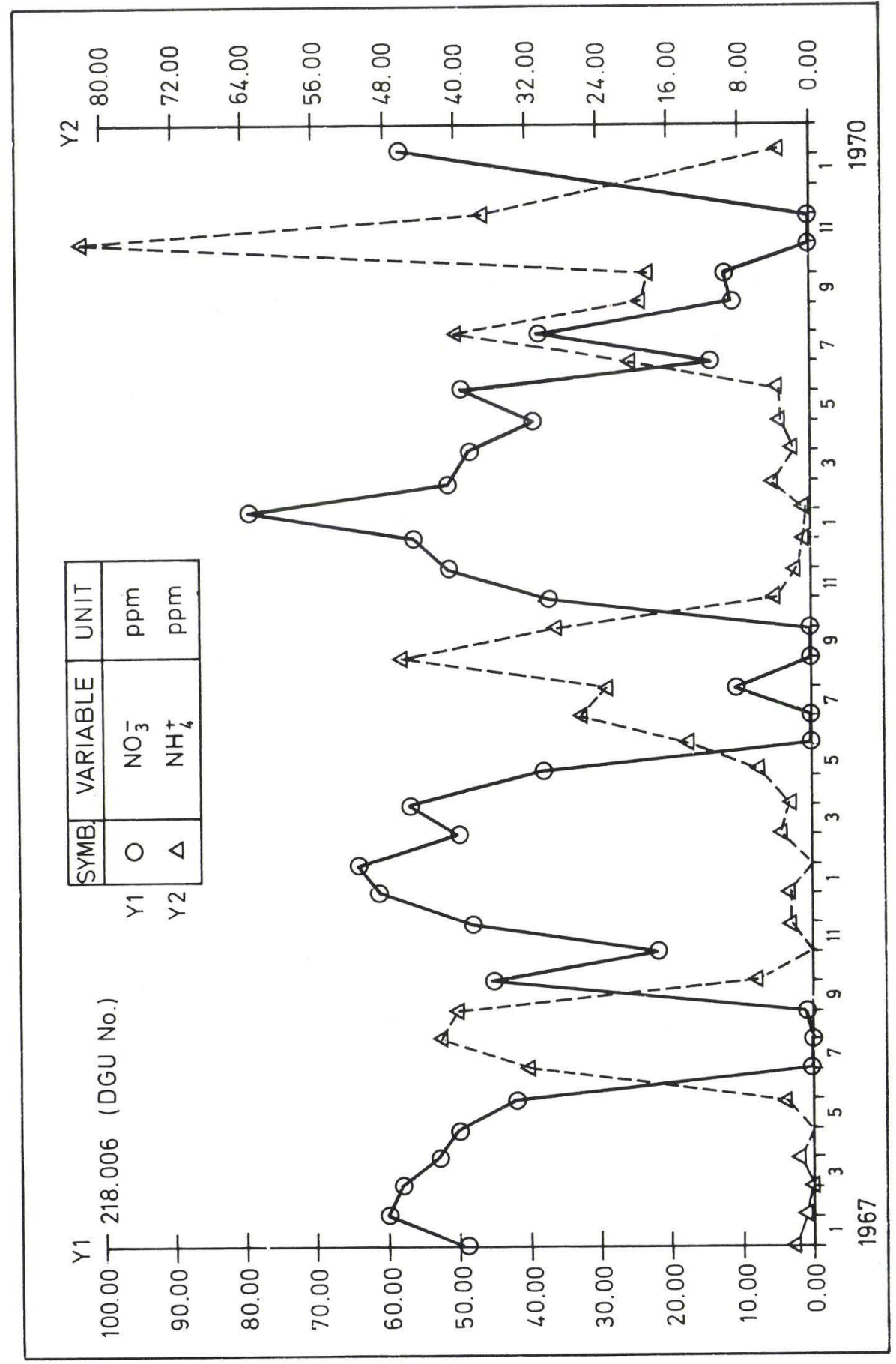


By activating different programmes stored on a partitioned dataset with direct access, the following outputs can be obtained:

Lists, in which any part of the data bank can be outlined.

Circle plot of single analyses (pie-diagram).

Histogram plot, which summarizes large-scale variations for single elements within greater areas.

Concentration plot, which illustrates in detail the variation of the variable in question from one locality to another.

Variation plot, by which the time variation for selected variable(s) is presented.

The data processing has led to a rationalization in the handling of the original files. This has resulted in an improvement in the Survey's ability to participate in investigations and research projects required e.g. by the counties, health authorities, and the Ministry of Environmental Protection.

The computer project should not be looked upon as finished. At the moment, for example, a statistical treatment of the data is going on, using library programmes.

Acknowledgements. As the economical possibilities initially were rather small, the Survey began its data processing with the aid of unpaid computer science students, who as part of their study at Copenhagen University must carry out practical work, preferably for users outside the university. Later on the necessary improvements and developments of the original programmes produced by the students were paid for by the Survey. The following students, who were involved in the development of the programmes, are kindly acknowledged:

Poul Østergård, Erik Dalsager, Carsten Henriksen, Vibeke Nielsen, and Ove A. K. Nielsen.

Fig. 9. Variation plot of $\mathrm{NO}_{3}^{-}$and $\mathrm{NH}_{4}{ }^{+}$for river station No. 218.006 (output from PLOT 3). 


\section{Dansk sammendrag}

\section{Kortlægning af hydrokemiske data ved hjælp af EDB}

Ved Danmarks Geologiske Unders $\varnothing$ gelse (DGU) oprettedes omkring 1930 et grundvandsanalysearkiv og midt $\mathrm{i}$ halvtredserne et overfladevandsarkiv, som i dag indeholder henholdsvis ca. 10.000 grundvandsanalyser og 10.12.000 overfladevandsanalyser fra alle egne af Danmark.

I forbindelse med den hydrogeologiske kortlægning, som i $\emptyset$ jeblikket foretages af amtskommunerne i medfør af vandforsyningsloven af 1973, anvendes grundvandsanalysearkivet som basis for fremstilling af kort over grundvandets kemiske sammensætning. Overfladevandsarkivet har især fundet anvendelse til belysning af de geokemiske tilstande i Danmark (forvitring, okkerforurening m.v.).

Med henblik på bedst muligt at udnytte de store mængder af informationer, som disse arkiver indeholder, til ovennævnte formål blev der i 1973 påbegyndt en EDB-bearbejdning af de to arkiver. Nærværende publikation indeholder en summarisk gennemgang af de udviklede programmer, og der gives eksempler på de grafiske fremstillinger af hydrokemiske data, som i $\emptyset$ jeblikket kan fremstilles på DGU.

Begge arkiverne er via hulkort overført til magnettapes på NEUCC (Danmarks tekniske Højskole), hvor regne- og plottearbejdet udf $\varnothing$ res. De af DGU udviklede programmer (se fig. 3) findes på dataset, ligeledes på NEUCC, og betjenes fra DGU's skærmterminal via telefonnettet.

For at bevare muligheden for manuelt at videref $\varnothing$ re de oprindelige vandanalysearkiver og samtidig begrænse udgifterne til hullearbejdet mest muligt benyttes specielle analyseblanketter (fig. 1).

De grafiske afbildninger af hydrokemiske data, der i øjeblikket kan fremstilles på DGU, er følgende:

1. Cirkelkort (fig. 6 og tavle I). De enkelte cirklers størrelse og opdeling viser den kemiske sammensætning af en enkelt vandpr $\varnothing v e$. Cirklerne monteres manuelt eller automatisk på kort og anvendes ved amternes igangværende hydrogeologiske kortlægning.

2. Histogramkort (tavle II). Histogramkortene viser hovedlinierne i et stofs fordelingsm $\varnothing$ nster inden for et større område. Tavle II viser således varia- 
tionen i grundvandets kloridindhold for hele Danmark. De enkelte histogrammer beregnes og sammenstilles automatisk.

3. Koncentrationskort (fig. 7). Denne type kort viser i detaljer koncentrationen af et bestemt stof (fig. 7, fluorid) ved en cirkelflade, hvis areal angiver koncentrationen. De enkelte cirkler placeres automatisk på det sted, hvor boringen er udført.

4. Variations-plot (fig. 8 og 9), som viser et eller flere udvalgte stoffers koncentration (y-aksen) mod tiden (x-aksen).

Herudover kan lister indeholdende udvalgte dele af databankerne fremstilles.

Ovennævnte typer af grafiske illustrationer har fundet anvendelse ved løsningen af en række praktiske problemer, hvor der kræves kendskab til grundvandets og overfladevandets kemiske forhold. Samtidig har opbygningen af de to databanker på EDB-læsbart medium muliggjort en fremtidig statistisk bearbejdning af analysematerialet, hvor det i vid udstrækning vil være muligt at udnytte foreliggende standardprogrammer. 


\section{Literature}

Hem, J. D. 1970: Study and Interpretation of the Chemical Characteristics of Natural Water. - U.S. Geol. Survey Water-Supply Paper 1473, 363 p.

Jacobsen, J. 1976: Mobilization, transportation, and sedimentation of weathering products from the abandoned brown-coal pits (Iron pollution of the river Skjerna and Ringkøbing fjord, Western Jutland). - Danm. geol. Unders., Årbog 1975, pp. 57-74. Villumsen, A. 1977: Mapping of ground-water chemistry in Denmark. - Striae, vol. 4. In press.

Vejledning i anvendelse af hydrogeologiske kort m.v. - København 1977, Miljøstyrelsen. In prep.

Eriksen, B., H. J. Helms \& M. D. Rømer 1971: EDB-ordbog. - Jul. Gjellerups Forlag, Kфbenhavn, 154 p. 

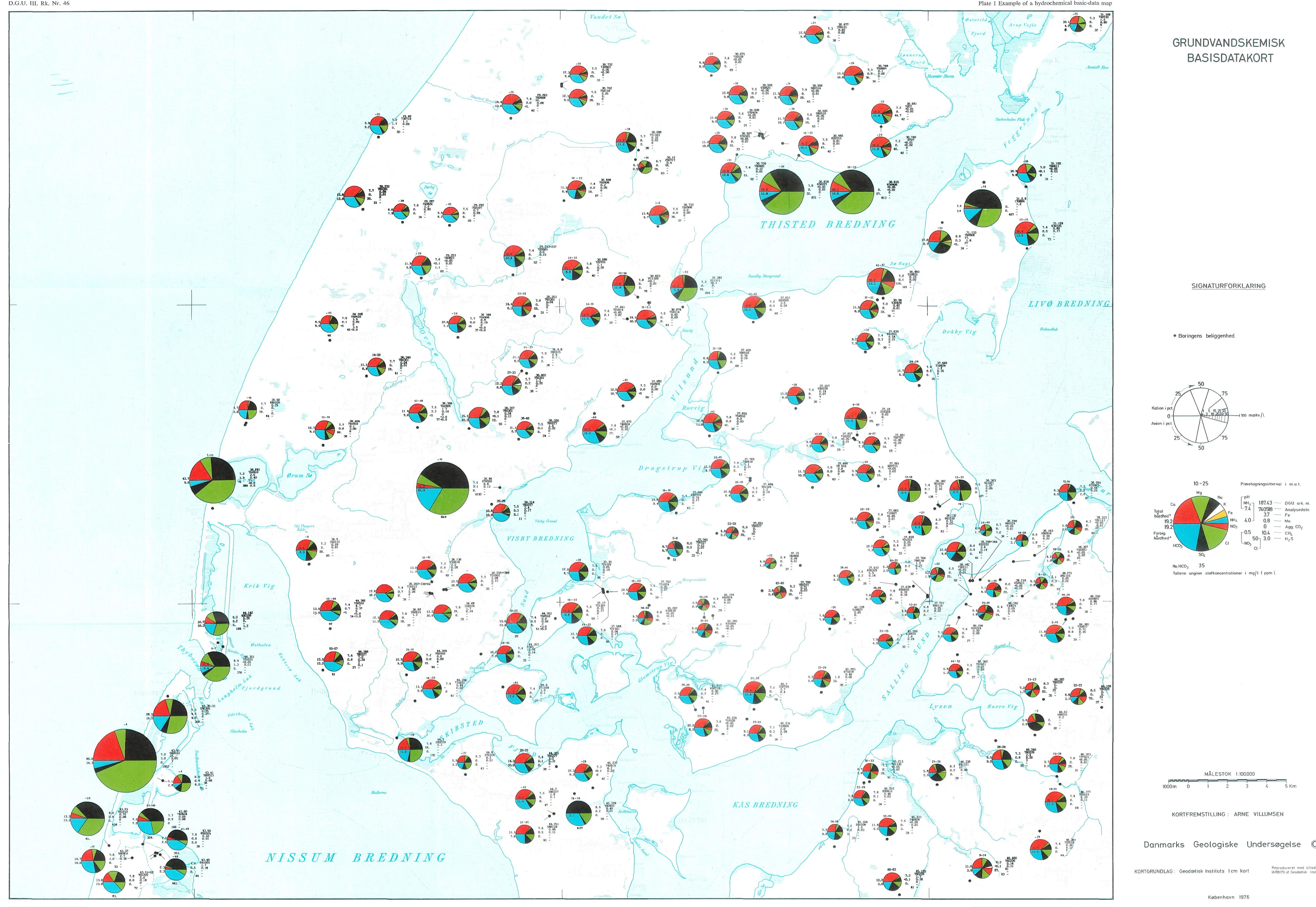

Danmarks Geologiske Undersøgelse

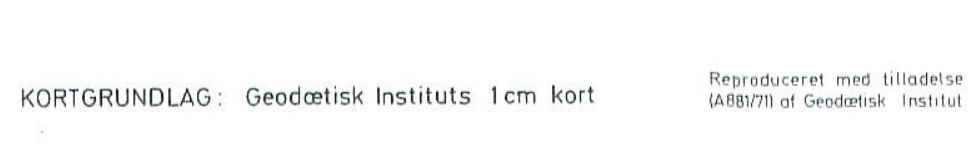




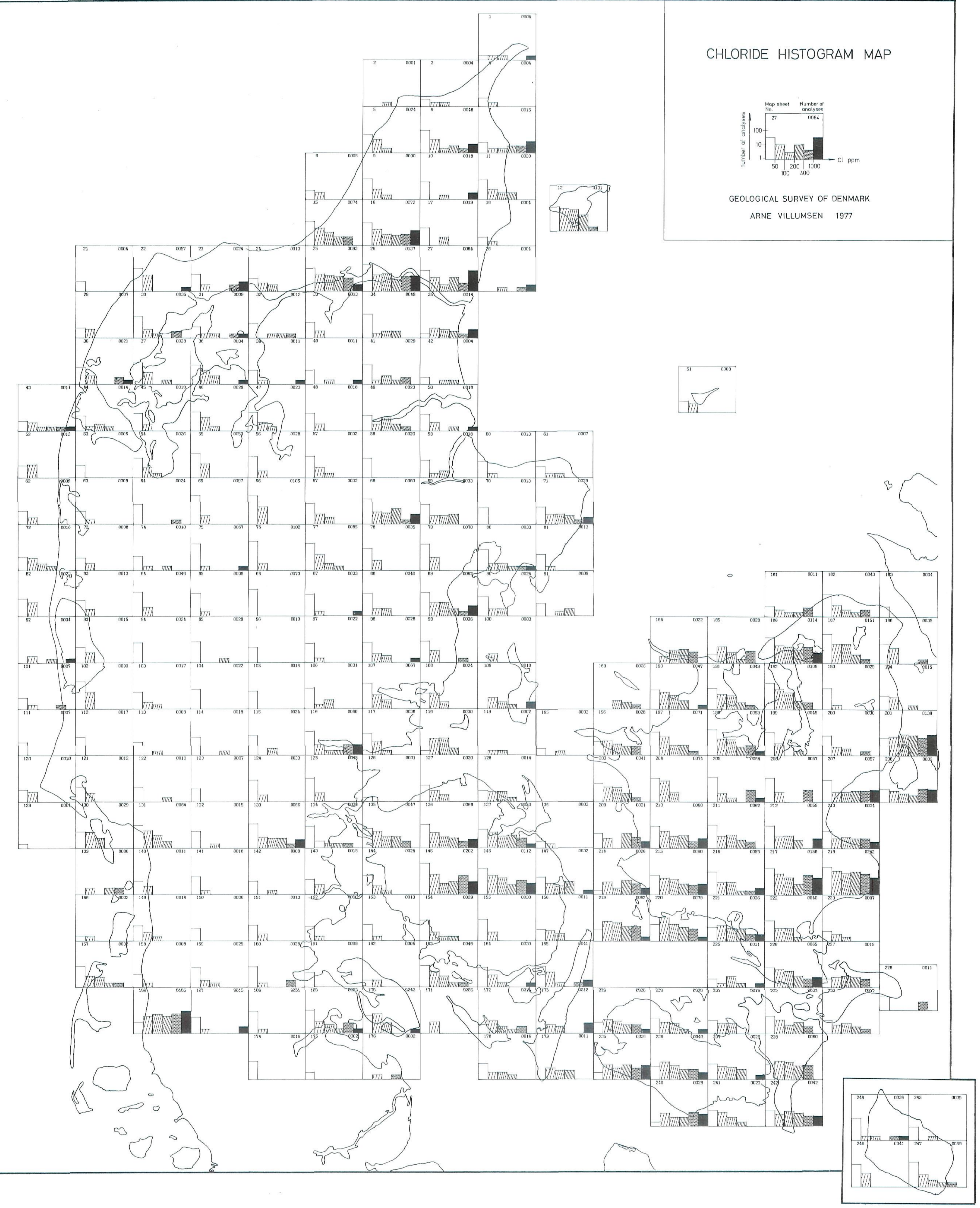

